\title{
Generalized Stratigraphy, Surficial Geology, Types of Aquifers, and 1988-89 Ground-Water Pumpage in Eastern Saratoga County, New York
}

By

Paul M. Heisig

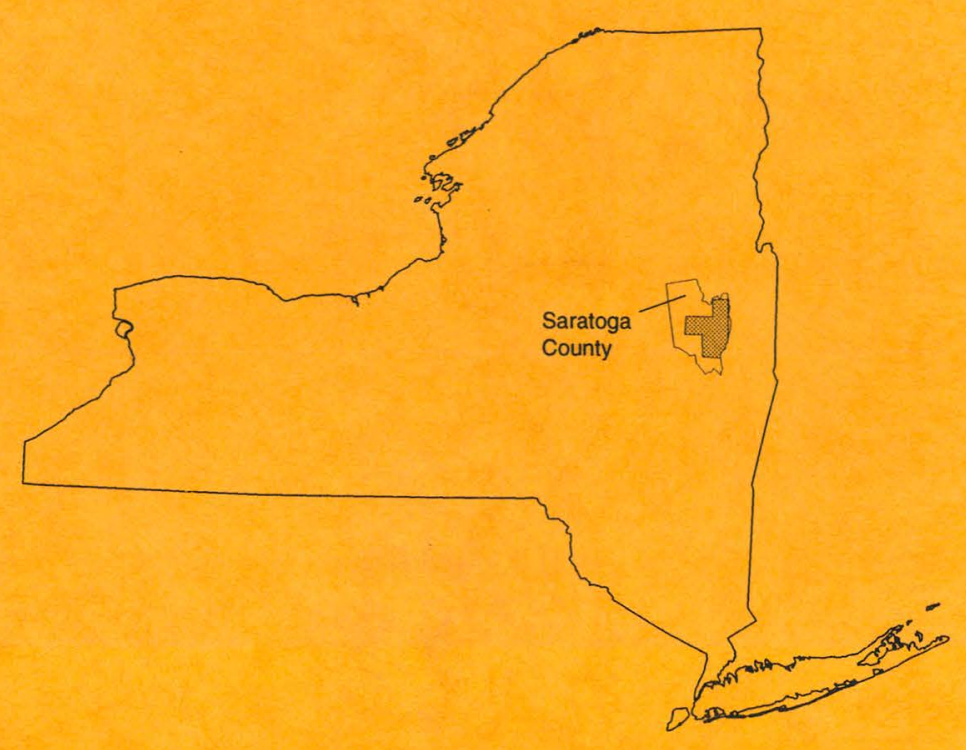

U.S. GEOLOGICAL SURVEY

WATER-RESOURCES INVESTIGATIONS REPORT 93-4029

Plates 1-8. Maps showing surficial geology, locations of buried bedrock channels, and locations of ground-water pumping facilities, Saratoga County, N.Y.

1. Gansevoort quadrangle

2. Quaker Springs quadrangle

3. Saratoga Springs quadrangle

4. Middle Grove quadrangle
5. Round Lake quadrangle

6. Mechanicville quadrangle

7. Niskayuna quadrangle

8. Troy North quadrangle

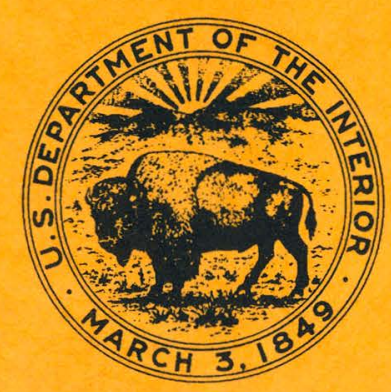

Prepared in cooperation with the SARATOGA COUNTY ENVIRONMENTAL MANAGEMENT COUNCIL 
Generalized Stratigraphy, Surficial Geology, Types of Aquifers, and 1988-89 Ground-Water Pumpage in Eastern Saratoga County, New York

U.S. GEOLOGICAL SURVEY Water-Resources Investigations Report 93-4029

Prepared in cooperation with the SARATOGA COUNTY ENVIRONMENTAL MANAGEMENT COUNCIL

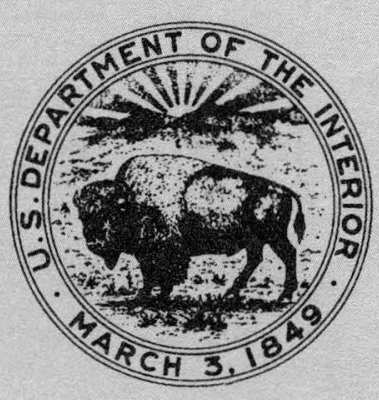


GENERALIZED STRATIGRAPHY, SURFICIAL GEOLOGY, TYPES OF AQUIFERS, AND 1988-89 GROUND-WATER PUMPAGE IN

EASTERN SARATOGA COUNTY, NEW YORK

By Paul M. Heisig

\section{U.S. GEOLOGICAL SURVEY}

Water-Resources Investigations Report 93-4029

Prepared in cooperation with the

SARATOGA COUNTY ENVIRONMENTAL MANAGEMENT COUNCIL

Albany, New York 


\title{
DEPARTMENT OF THE INTERIOR
}

\section{BRUCE BABBITT, Secretary}

\author{
U.S. GEOLOGICAL SURVEY
}

Gordon P. Eaton, Director

For additional information write to:

U.S. Geological Survey

P.O. Box 1669

Albany, NY 12201
Copies of this report may be purchased from:

U.S. Geological Survey Books and Open-File Reports-ESIC P.O. Box 25286

Denver, CO 80225 


\section{CONTENTS}

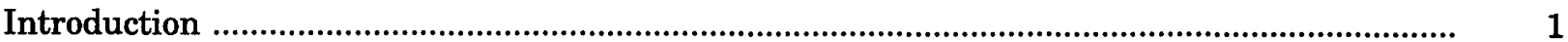

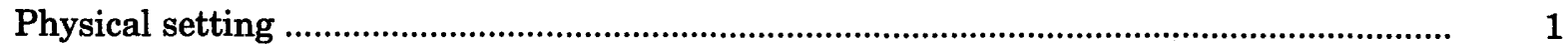

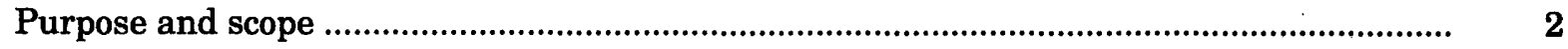

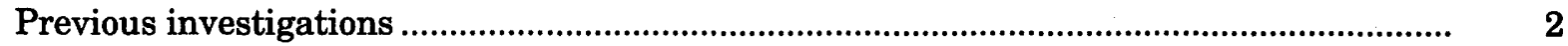

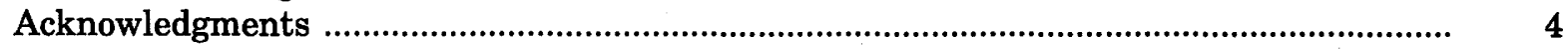

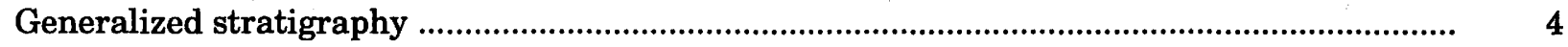

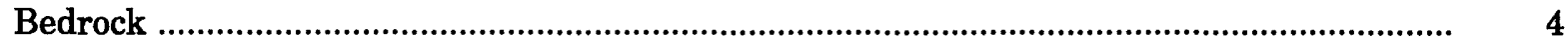

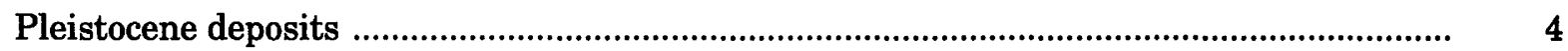

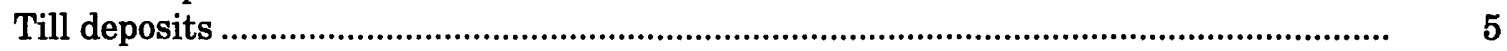

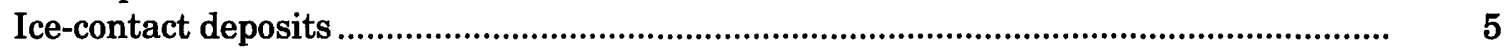

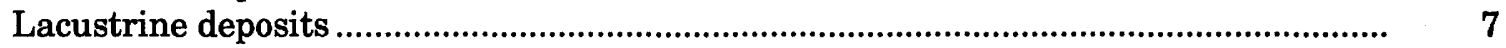

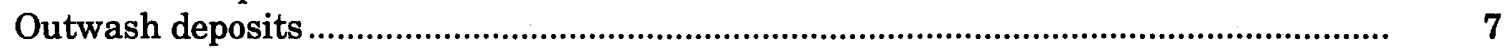

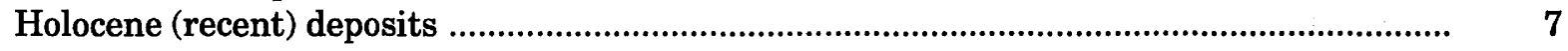

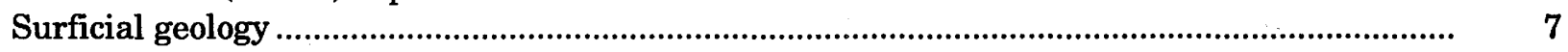

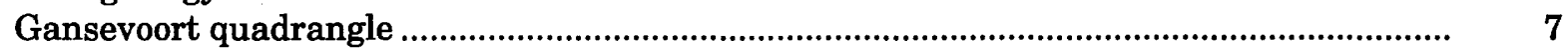

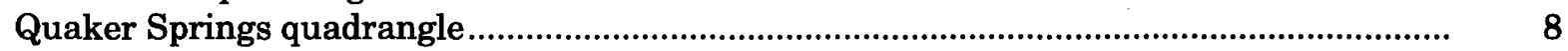

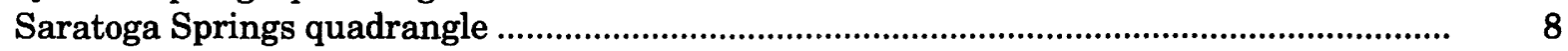

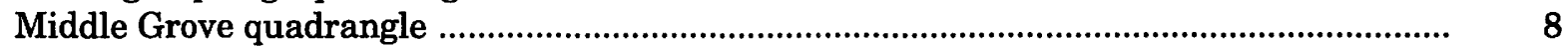

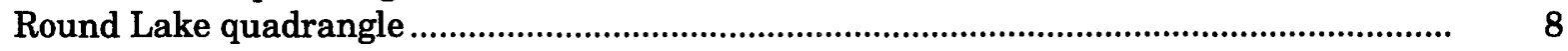

Mechanicville quadrangle .................................................................................................... 9

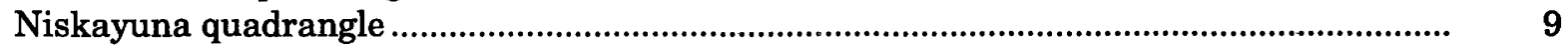

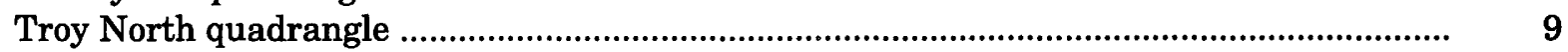

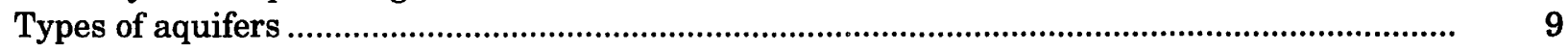

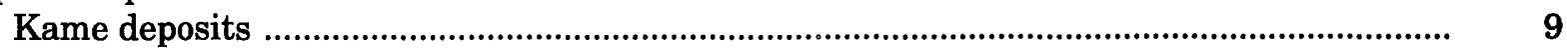

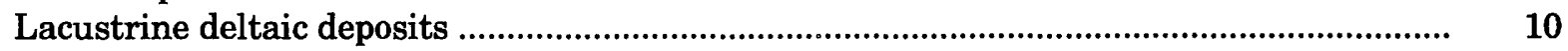

Lacustrine sand, outwash sand and gravel, and alluvium ................................................ 10

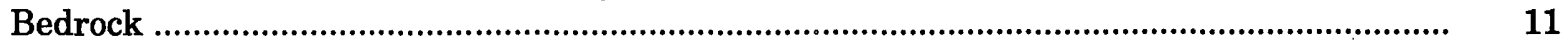

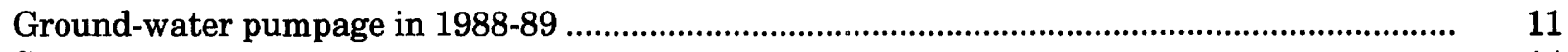

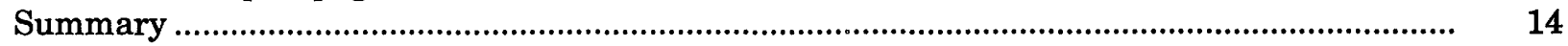

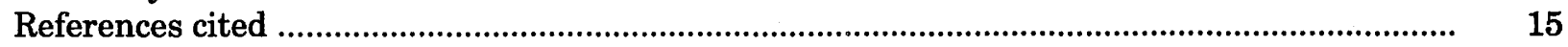

\section{ILLUSTRATIONS}

(plates are in pocket)

Plates 1-8: Maps showing surficial geology, locations of buried bedrock channels, and locations of ground-water pumping facilities, Saratoga County, N.Y.

1. Gansevoort quadrangle

2. Quaker Springs quadrangle

3. Saratoga Springs quadrangle

4. Middle Grove quadrangle

5. Round Lake quadrangle

6. Mechanicville quadrangle

7. Niskayuna quadrangle

8. Troy North quadrangle 


\section{ILLUSTRATIONS (CONTINUED)}

Figure 1. Map showing major geographic features of Saratoga County and vicinity and location of study area

2. Map showing names and locations of the eight $7^{1 / /}$-minute quadrangles and geographic features in eastern Saratoga County that are depicted in plates 1 through 8

3. Block diagram showing generalized stratigraphy of Pleistocene and Holocene (recent) deposits in eastern Saratoga County

\section{TABLES}

Table 1. Description of unconsolidated deposits in the study area

2. Hydraulic characteristics of unconsolidated deposits in the study area

3. Average daily pumpage (1988-89), aquifer type, and well data from suppliers that withdraw at least 10,000 gallons per day in eastern Saratoga County, arranged by facility

4. Pumpage totals, by suppliers listed in table 3 .

\section{CONVERSION FACTORS}

\begin{tabular}{lcl}
\hline \multicolumn{1}{c}{ Multiply } & By & To obtain \\
\hline inch (in) & Length & \\
inch (in) & 2.54 & centimeter \\
foot (ft) & 25.4 & millimeter \\
mile (mi) & 0.3048 & meter \\
& 1.609 & kilometer \\
acre & Area & \\
& 0.4047 & hectare \\
square mile (mi ${ }^{2}$ ) & 0.09294 & square meter \\
& 2.59 & square kilometer \\
& & \\
gallon (gal) & Volume & \\
& 3.785 & liter \\
foot per second (ft/s) & & \\
foot per day (ft/d) & Flow & \\
cubic foot per second $\left(\mathrm{ft}^{3} / \mathrm{s}\right)$ & 0.3048 & meter per second \\
gallon per minute (gal/min) & 0.3048 & meter per day \\
gallon per day (gal/d) & 0.02832 & cubic meter per minute \\
million gallons per day (Mgal/d) & 3.7848 & liter per minute \\
& 0.003785 & cubic meter per day \\
cubic meter per second
\end{tabular}

Sea level: In this report "sea level" refers to the National Geodetic Vertical Datum of 1929 (NGVD of 1929)-a geodetic datum derived from a general adjustment of the firstorder level nets of both the United States and Canada, formerly called Sea level datum of 1929. 


\title{
GENERALIZED STRATIGRAPHY, SURFICIAL GEOLOGY, TYPES OF AQUIFERS, AND 1988-89 GROUND-WATER PUMPAGE IN EASTERN SARATOGA COUNTY, NEW YORK
}

\author{
By
}

\author{
Paul M. Heisig
}

\begin{abstract}
The eastern part of Saratoga County, N.Y., has undergone considerable population growth and development since 1963, when the completion of Interstate 87 increased accessibility to the Capital District, 30 miles to the south. Since then, nearly all housing developments along the Interstate 87 corridor have obtained their water supply from discontinuous Pleistocene-age sand and gravel aquifers. This report describes the generalized stratigraphy of Pleistocene and Holocene (recent) sediments, as well as two general types of aquifer (bedrock and unconsolidated), and presents data on 1988-89 ground-water pumpage in eastern Saratoga County. Surficial geology, locations of preglacial buried bedrock channels, and ground-water pumpage by facilities that withdraw at least 10,000 gallons per day are indicated on eight 1:24,000-scale topographic $7{ }^{1 /} /{ }_{2}$-minute quadrangle sheets (Gansevoort, Quaker Springs, Saratoga Springs, Middle Grove, Round Lake, Mechanicville, Niskayuna, and Troy North). In general, water suppliers obtain more water from unconsolidated aquifers than from bedrock aquifers because the unconsolidated aquifers are more productive. The most productive confined aquifers in the area are kame and lacustrine deltaic deposits, and the most productive unconfined aquifers are outwash or alluvial deposits that are hydraulically connected to surface-water bodies. Lacustrine sand forms a thin, but extensive, aquifer best suited for pumping by shallow wells. The water-resource potential of exposed kame and buried-channel deposits north of Saratoga Lake is largely unknown.
\end{abstract}

\section{INTRODUCTION}

Population growth and development along the Interstate 87 corridor in Saratoga County for the last 30 years has increased the use of ground water for community water supply and, to a lesser extent, for industry. Much of this growth is a result of the completion of Interstate 87 in 1963 (fig. 1), which increased accessibility to the Capital District (cities of Albany, Troy and Schenectady). Although public water supply in Saratoga County is drawn from both surfacewater and ground-water sources, nearly all new development has used ground water as the sole source of supply. Thus, information on groundwater resources in this area is necessary for development and protection of present and future supplies.

In response to the county's need for hydrologic information, the U.S. Geological Survey (USGS), in cooperation with the Saratoga County Environmental Management Council, began a study in 1988 to compile and analyze data on the ground-water resources in eight $7{ }^{1 / 2} 2^{-}$ minute quadrangles that encompass the eastern part of the county (fig. 2). The investigation entailed the compilation of surficial geology, delineation of preglacial bedrock channels, and compilation of well-depth and pumpage data.

\section{Physical Setting}

The study area is in the northern HudsonMohawk Lowlands (fig. 1). The area is characterized by low relief and by deposits of Pleistocene age as thick as $300 \mathrm{ft}$ (Reynolds, 1985) that overlie a dissected bedrock surface that was modified by glacial erosion. The deepest of several bedrock channels within the study area is the Colonie channel (Simpson, 1949), which extends to below sea level in places (Dineen and Hanson, 1983; Dineen, 1975-88). Bedrock in the 


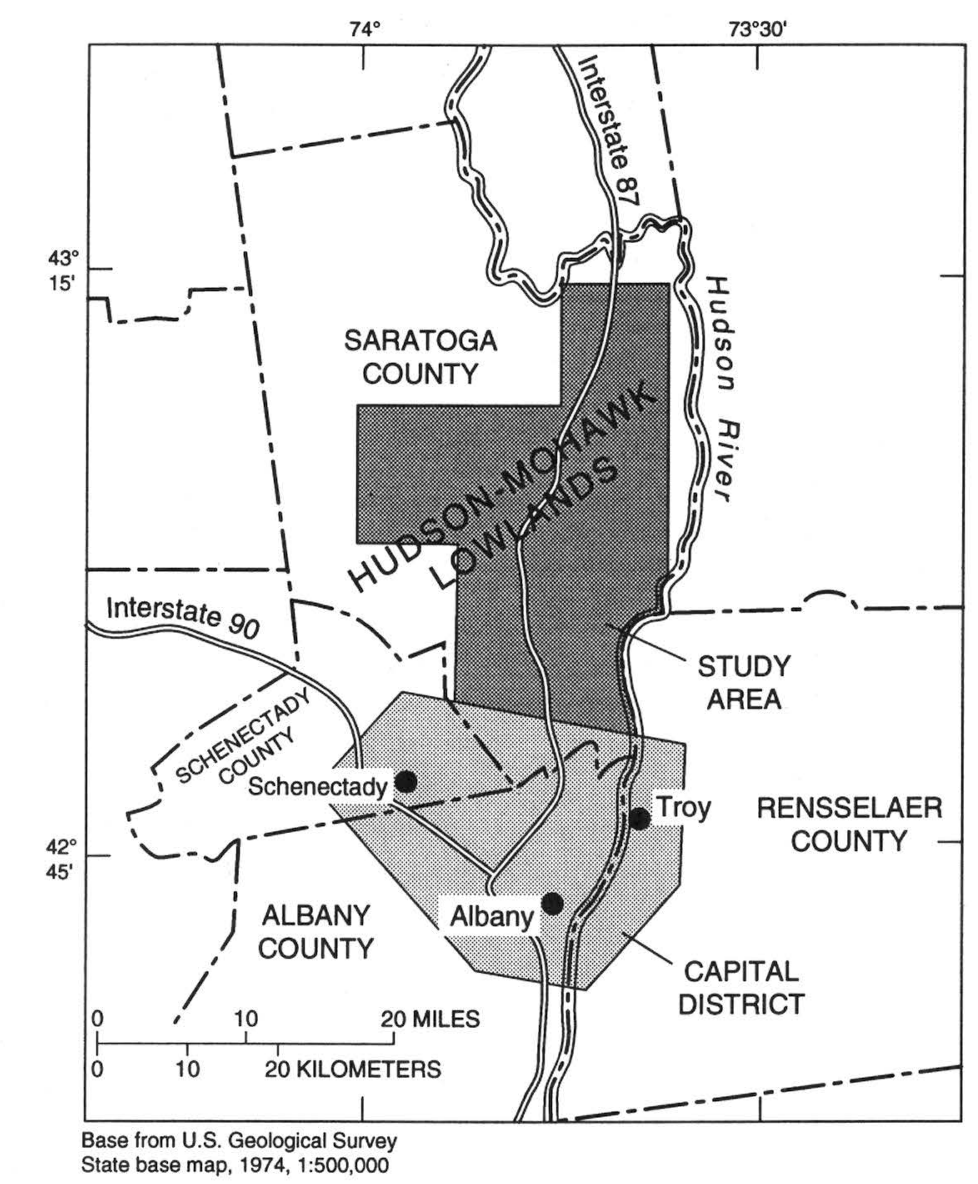

Figure 1.-Major geographic features of Saratoga County and vicinity, and location of study area .

area consists of shale and graywacke of Ordovician age, except in the northern and eastern parts of the study area, where it consists of older sandstone, carbonate, and crystalline rock. Most surface water drains eastward into the Hudson River through three drainage systems: (1) Kayaderosseras Creek, Saratoga Lake, and Fish Creek, (2) Ballston Lake, Ballston Creek, Round Lake, and Anthony Kill, and (3) Snook Kill (fig. 2).

\section{Purpose and Scope}

This report discusses the general stratigraphy, surficial geology, types of aquifers, and 1988-89 ground-water pumpage in eastern Saratoga County. The generalized stratigraphic relations of unconsolidated deposits are presented in a block diagram, and well pumpage, well depth, and type of aquifer tapped by yearround suppliers that withdraw at least 10,000 gal/d are tabulated. Plates 1-8 depict the surficial geology, delineate thalwegs (deepest courses) of preglacial buried bedrock channels, and show water-supplier locations and average daily pumpage in the eight $7{ }^{1} / 2^{-m i n u t e ~ q u a d-~}$ rangles that form the study area.

\section{Previous Investigations}

Glacial geology of the study area has been described by several investigators. Stoller (1916) discussed the glacial geology of the Saratoga quadrangle, and LaFleur (1965, 1979), Dineen and Rogers (1979), and DeSimone and LaFleur (1985) investigated glacial-lake stages, deglacial events, and depositional environments in the Hudson-Mohawk lowlands. Fairchild (1917) discussed postglacial features of the upper Hudson valley, and Hanson (1977) reported on the Late Woodfordian drainage history of the lower Mohawk valley.

Heath (1963) summarized ground-water 


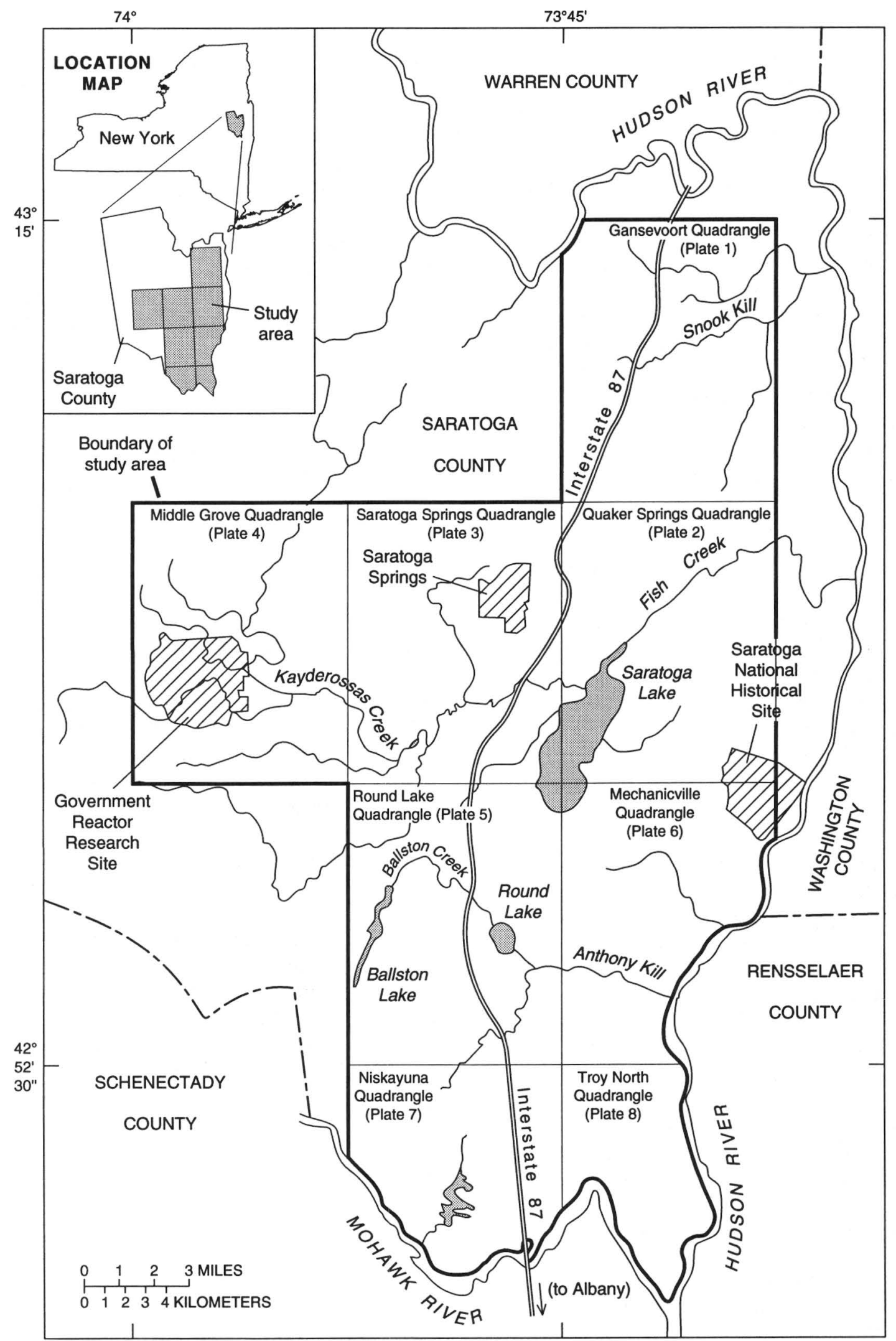

Base from U.S. Geological Survey, Heath, 1963, fig. 1-3

Figure 2.-Names and locations of eight 7-1/1/ $2^{-m i n u t e ~ q u a d r a n g l e s ~ a n d ~ g e o g r a p h i c ~ f e a t u r e s ~}$ in eastern Saratoga County that are depicted in plates 1 through 8. 
conditions in Saratoga County, and Mack and others (1964), Mack (1963), and Heath and Tannenbaum (1963) studied sites at West Milton and the Saratoga National Historical Park, respectively.

Simpson (1949) first identified and mapped buried preglacial bedrock channels, including the Colonie channel, in the Capital District (south of the study area) and recognized the value of the valley-fill aquifers as potential sources of ground water. Dineen and Hanson (1983) mapped and described bedrock topography and glacial deposits of the Colonie channel as far north as Saratoga Lake. Dunn Geoscience Corporation (1981, 1982) and Reynolds (1985) investigated the hydrogeology of the Clifton Park area of Saratoga County, including the Colonie channel aquifers and their recharge areas. Waller (1983) used test-hole data to describe the ground-water potential of buried valley deposits in the Capital District.

\section{Acknowledgments}

The author thanks the New York State Geological Survey, which provided maps of surficial geology and bedrock-surface altitude that were used to establish the location of the buried Colonie channel and associated channels north of Saratoga Lake. Walter Bundy of the New York State Department of Health, Bureau of Public Water Supply Protection, provided much of the 1988-89 pumpage data. Many water suppliers provided well and pumpage data.

\section{GENERALIZED STRATIGRAPHY}

The stratigraphy of eastern Saratoga County is characterized by a sequence of Precambrianto Ordovician-age bedrock units that are overlain almost everywhere by unconsolidated Pleistocene and Holocene (recent) deposits of variable thickness and composition.

\section{Bedrock}

Four general types of bedrock underlie eastern Saratoga County, including from oldest to youngest, crystalline rocks, sandstone, carbonate rocks, and shale (Heath, 1963). The crystalline rocks are a mixture of igneous and metamorphic rock and are of Precambrian age. The Cambrian-age sandstone unit, which contains dolomite interbeds near the top, overlies the crystalline rocks and is 200 to $400 \mathrm{ft}$ thick (Heath, 1963). Carbonate rocks (limestone and dolomite) of Ordovician age overlie the sandstone and are 300 to $400 \mathrm{ft}$ thick in most places (Heath, 1963). The three aforementioned units crop out along the northwestern edge of the study area. The youngest bedrock unit consists of a series of shales of Ordovician age ( 300 to $1,000 \mathrm{ft}$ thick). This unit forms the bedrock surface throughout most of the study area (Heath, 1963).

The bedrock surface of the study area has been modified by faulting and erosion. Northeast-trending faults along the northwest edge of the study area (Heath, 1963) account for much of the topographic relief and the exposure of older bedrock units in this area.

The bedrock surface is characterized by several preglacial channels that were enlarged and subsequently filled and buried through glacial processes. Delineation of such channels is important because some of the most productive aquifers in the study area are within the channels. The thalweg, or deepest course, of each channel is depicted, along with approximate elevations, in plates 1 through 5 and 7. (No buried channels have been identified in the areas shown in plates 6 and 8.) Channel delineations south of Saratoga Lake are based on investigations by Reynolds (1985) and Dineen and Hanson (1983); those north and west of Saratoga Lake are based on bedrock-surface maps by Dineen (1975-88). The greatest channel-fill thicknesses are found along the Colonie channel (Simpson, 1949), which trends north-south through the study area (pls. 1-3, 5, and 7) and is characterized by a broad channel with a V-shaped inner gorge (Dineen and Hanson, 1983).

\section{Pleistocene Deposits}

Pleistocene deposits provide a partial record of the sequence of events and depositional environments during deglaciation of the study area. These events include retreat of the ice front in conjunction with the formation of a time sequence of successively lower stage proglacial 
lakes in the Hudson River basin as well as major changes in surface-water drainage. A full account of the deglacial history of the study area is beyond the scope of this report; the reader is referred to LaFleur (1979) and Hanson (1977). Pleistocene deposits in the study area represent several types of depositional environments, some of which extended for many square miles, and some of which were localized. A description of each type of deposit and its depositional environment is given in table 1; the generalized stratigraphy and distribution of Pleistocene and Holocene deposits typical of the study area are illustrated in figure 3. Pleistocene deposits can be grouped into four general categories: till, icecontact material, lacustrine material, and outwash.

\section{Till Deposits}

Till is an unsorted mixture of rock fragments ranging in size from clay to boulders. It commonly overlies the bedrock surface and is probably the most extensive glacial deposit in the study area. Thickness is generally less than
$50 \mathrm{ft}$ (Hanson, 1977) but locally is as much as $250 \mathrm{ft}$, especially in buried valleys and drumlinoid features (elongated ridges parallel to ice movement that consist of till, and can be bedrock cored). Till generally is present as a surficial deposit at altitudes ${ }^{1}$ above 330 to $400 \mathrm{ft}$, the maximum stage of glacial Lake Albany (DeSimone and LaFleur, 1985), or where erosion has removed overlying kame or glacial-lake sediments.

\section{Ice-Contact Deposits}

Ice contact is a general term for stratified, predominantly coarse-grained sediments that were deposited within, against, or atop stagnant or retreating ice masses. These deposits overlie till or bedrock upon which they were deposited during ice meltout or collapse and typically are locally variable with respect to sorting, coarseness, and thickness. Some common types of icecontact deposits include kames, eskers, kame

${ }^{1}$ In this report, altitudes are given in feet above sea level.

\section{EXPLANATION}

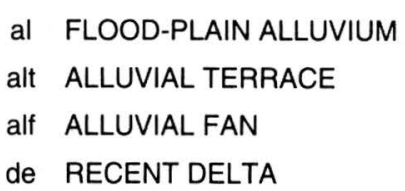

de RECENT DELTA

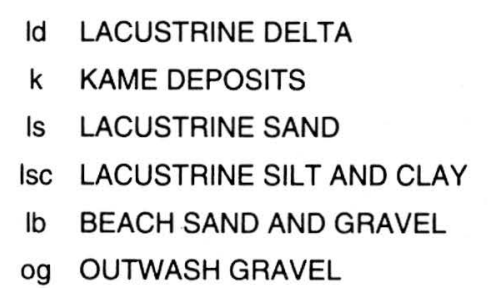

1 TILL

tt THIN TILL

tw WASHED TILL

pm SWAMP DEPOSITS

d DUNES

$r$ BEDROCK

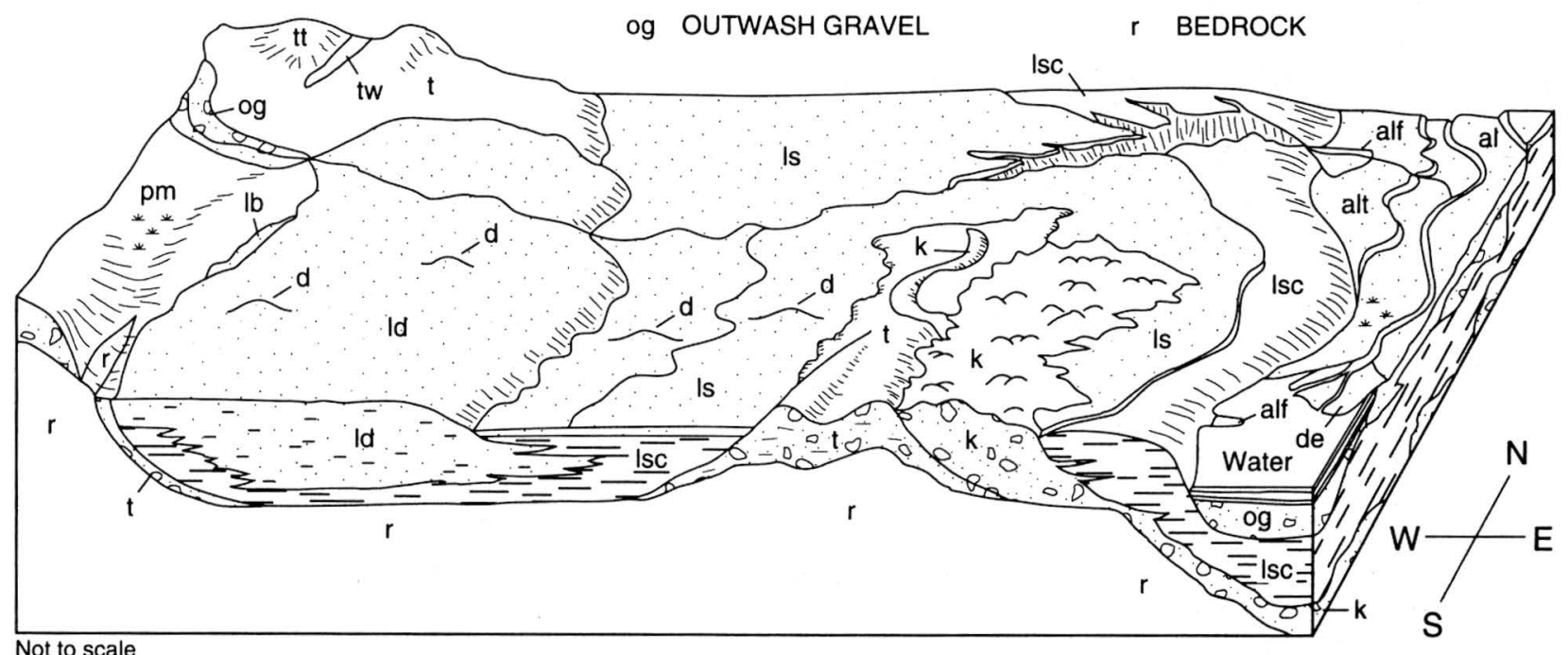

Figure 3.-Generalized stratigraphy of Pleistocene and Holocene (recent) deposits in eastern Saratoga County. 
terraces, kame deltas, kame moraines, esker deltas, and subaqueous fans. Ice-contact deposits are undifferentiated in plates 1 through 8 to comply with New York State Geological Survey terminology, wherein all ice-contact deposits are identified as "kame deposits." Therefore, the term "kame deposits," as used in this report, refers to undifferentiated ice-contact deposits.

Table 1.-Description of unconsolidated deposits in the study area.

[it, feet]

Map

Symbol
Description

\section{Holocene Deposits}

al FLOOD-PLAIN ALLUVIUM-recent deposits derived from periodic flooding within a stream valley; generally fine sand and gravel, although sediments commonly reflect the character of the deposits that the stream traverses. Up to $10 \mathrm{ft}$ thick.

alt ALLUVIAL TERRACE-glacial and postglacial deposits of fluvial sand and gravel, laterally continuous lenses of silt (flood-plain alluvium deposited at a higher level than the recent flood plain). Up to $50 \mathrm{ft}$ thick.

alf ALLUVIAL FAN-fan-shaped accumulation of alluvium produced by a stream as it flows from sloped valley walls onto a level flood plain; poorly stratified silt, sand, and cobbles. Up to $20 \mathrm{ft}$ thick.

de RECENT DELTA-gravel and sand deposited by tributary streams at a lakeshore. Thickness variable.

pm SWAMP DEPOSITS—peat, muck, organic silt, and sand in poorly drained areas. Up to $20 \mathrm{ft}$ thick.

d DUNES-fine to medium sand, well sorted, stratified; generally reworked lacustrine sand and deltaic deposits. Up to $50 \mathrm{ft}$ thick.

\section{Pleistocene Deposits}

lb BEACH SAND AND GRAVEL-well-sorted sand and gravel deposited as beaches that were associated with large proglacial lakes.

ld LACUSTRINE DELTA-gravel and sand, stratified, generally well sorted, deposited at former glacial lakeshore. Up to $120 \mathrm{ft}$ thick.

ls LACUSTRINE SAND-sand deposits associated with large proglacial lakes, formerly a near-shore deposit or subaqueous (underwater) fan. Well sorted, stratified, generally fine to very fine sand. Up to $95 \mathrm{ft}$ thick.

Isc LACUSTRINE SILT AND CLAY-Laminated silt and clay deposited in proglacial lakes. Thickness variable but is up to $275 \mathrm{ft}$ in parts of the Colonie channel (Reynolds, 1985).

fg FLUVIAL GRAVEL-fluvial sand and gravel, age uncertain; up to $20 \mathrm{ft}$ thick.

og OUTWASH SAND AND GRAVEL-sand and gravel deposited by meltwater from retreating glacial ice. Well rounded and stratified, texture becomes increasingly fine away from ice border. Up to 25 $\mathrm{ft}$ thick.

k KAME DEPOSITS-a stratified mix of cobbles, gravel, sand, silt and clay that was deposited by glacial meltwater in contact with stagnant glacial ice. Large variability in sorting, particle size, and bed thickness. These ice-contact deposits include kames, eskers, kame terraces, kame deltas, esker deltas, and subaqueous fans. Up to $100 \mathrm{ft}$ thick.

cd COMPLEX DRIFT-large variability in composition over short distances. Ranges from ice-contact sand and gravel to lacustrine sand, silt, and clay, and till. Forms scarps on either side of the Hudson River flood plain.

$\mathrm{t}$ TILL-lodgment or ablation till of variable thickness and texture. Up to $250 \mathrm{ft}$ thick. Texture ranges from clayey silt to boulder-bearing clay.

$\mathrm{t} t$ THIN TILL-variable mantle of rock debris and till of variable thickness. Bedrock sporadically crops out. Generally less than $10 \mathrm{ft}$ thick.

tw WASHED TILL-veneers of cobbles and boulders in surface channels and terraces in thick till deposits. Can show imbricate bedding structure. Generally less than $10 \mathrm{ft}$ thick. 


\section{Lacustrine Deposits}

As the glacial-ice margin retreated northward, meltwater became impounded and formed glacial Lake Albany, which stood at elevations between 330 and $400 \mathrm{ft}$ (LaFleur, 1965; Hanson, 1977; DeSimone and LaFleur, 1985). These elevations represent lake stage near Albany and Moreau State Park (Gansevoort quadrangle), respectively, and indicate a tilted glacial-lake water plane at present, which was caused by rebound of the land surface to the north after retreat of the ice front. The maximum stage (glacial Lake Albany) was followed by several successively lower lake stages (LaFleur, 1965; Hanson, 1977; DeSimone and LaFleur, 1985). The Pleistocene sediments associated with these lake stages include lacustrine silt and clay, lacustrine sand, lacustrine deltas, and lacustrine beach deposits. Silt and clay forms the most extensive and thickest lacustrine deposit in the study area, and its thickness ranges up to $275 \mathrm{ft}$ (Reynolds, 1985). Silt and clay commonly overlies till and kame deposits and, in turn, is typically overlain by lacustrine sand or alluvial deposits. Silt and clay are exposed at land surface where lacustrine sand and alluvial deposits either were not deposited or have been eroded. Most lacustrine sand deposits in this area are 20 to $50 \mathrm{ft}$ thick and have typically been reworked into sand dunes at land surface. In some areas, the sand directly overlies older
Pleistocene ice-contact sediments. Lacustrine deltaic deposits are commonly elevated above, and interfinger with, adjacent lake-bottom sediments. Another lacustrine delta is found above the highest level of glacial Lake Albany, where it was deposited in an impounded water body along the ice margin during deglaciation.

\section{Outwash Deposits}

Outwash is a stratified deposit composed primarily of sand and gravel derived from meltwater outflow from a glacier. It is deposited beyond the active margin or the end moraine of the glacier. Outwash is present as a surficial deposit along the Kayaderosseras Creek (Middle Grove quadrangle, pl. 4), which is higher in elevation than the maximum stage of glacial Lake Albany.

\section{Holocene (recent) Deposits}

Recent deposits in the study area consist of alluvium, alluvial-terrace, alluvial-fan, dune, and swamp deposits. Alluvial deposits most commonly overlie the Pleistocene or glacial deposits and form flood plains along stream or river courses. In some areas, extensive lacustrine delta and lacustrine sand deposits became exposed after Lake Albany drained to lower levels and then were reworked by wind into dunes and dune fields.

\section{SURFICIAL GEOLOGY}

The surficial geology of the study area is depicted on plates 1 through 8 . The distributions of surficial units form generalized patterns that are consistent on all of the maps; namely that till and bedrock are most commonly exposed in the uplands, kame-deposit exposures generally border the uplands, and lacustrine-deposit exposures predominate in areas of low elevation and low relief. The boundary between lacustrine deposits and other surficial material is typically at elevations of 330 to $400 \mathrm{ft}$, the highest stage of glacial Lake Albany, but isolated lacustrine deposits can be found at higher elevations wherever meltwater drainage was locally impounded by ice or glacial drift. Till, kame deposits, and bedrock are present at land surface locally at low elevations wherever the overlying lacustrine deposits have been eroded. An ex- ample of a lacustrine deposit at a high (above $400 \mathrm{ft}$ ) elevation is the Milton delta (Stoller, 1916), a deltaic deposit that lies at $420 \mathrm{ft}$ within the Saratoga Springs and Middle Grove quadrangles (pls. 3 and 4). An example of till, bedrock, and kame deposits exposed at a low elevation (below $330 \mathrm{ft}$ ) is the postglacial valley now occupied by Ballston Lake (pl. 5).

Holocene alluvium is found along presentday drainage courses. Alluvial-terrace deposits are found alongside and, especially, near the mouth of former postglacial drainage courses.

\section{Gansevoort Quadrangle}

Except in its northwestern corner and occasional drumlinoid (till) features, lacustrine deposits are predominant in the Gansevoort 
quadrangle (pl. 1). Sand plains and dune fields derived from lacustrine sand cover the surface and form a broad plain that has been partly dissected by the Snook Kill and its tributaries (fig. 2).

Exposures in the dissected areas reveal that the lacustrine sand forms a veneer over a thicker sequence of lacustrine silt and clay. In the northwestern corner of the quadrangle is a bedrock upland (the Palmerton Range), which is separated from the lacustrine deposits by narrow, discontinuous till bodies and a large kame deposit.

\section{Quaker Springs Quadrangle}

The Quaker Springs quadrangle (pl. 2) is characterized by two general areas, one of low relief and one of moderate relief, that flank the Saratoga Lake - Fish Creek drainage (fig. 2). The low-relief area that occupies the northwestern part of the quadrangle is predominantly lacustrine sand, although an area just north of Saratoga Lake contains extensive alluvialterrace deposits. Lacustrine silt and clay is not extensively exposed at land surface because the overlying sand plain in this part of the quadrangle is relatively undissected by streams. Southeast of the Saratoga Lake - Fish Creek drainage, deposits of lacustrine and dune sand decrease in number, and till, bedrock outcrops, and lacustrine silt and clay become increasingly common with increasing elevation and relief.

\section{Saratoga Springs Quadrangle}

The Saratoga Springs quadrangle (pl. 3) is characterized by a wide variety of surficial deposits. The northwest and north-central parts are at higher elevations and have greater relief than the rest of the quadrangle; thus, till and bedrock outcrops predominate here. A discontinuous band of kame deposits follows the southern boundary of the till and bedrock uplands north and west of Saratoga Springs. Most of the surficial deposits in the rest of the quadrangle consist of lacustrine and alluvial deposits. The lacustrine deposits include sand and gravel, sand, and silt and clay. A lacustrine deltaic deposit, the Milton delta (Stoller, 1916), is the dominant topographic feature in the southwestern quarter of the quadrangle. Lacustrine sand forms a broad plain over the central and northeastern parts of the quadrangle and also caps the Malta Ridge in the southeastern corner. Lacustrine silt and clay is relatively sparse in this quadrangle and does not underlie the lacustrine sand everywhere.

The area in the southeastern part of the quadrangle has largely been dissected by glacial meltwaters in the area now occupied by Kayaderosseras Creek. Alluvial-terrace and washed-till deposits are common in this area.

\section{Middle Grove Quadrangle}

The Middle Grove quadrangle (pl. 4) lies entirely above the elevation of the maximum stage of glacial Lake Albany (330 to $400 \mathrm{ft}$ ) and, therefore, lacks extensive deposits of lacustrine sand, silt, and clay. Instead, it is overlain largely by till and kame deposits; till mantles most topographic highs, whereas kame deposits flank the hills and cover much of the land at lower elevations. Two other surficial materials are present within the quadrangle: outwash gravel occupies the Kayaderosseras Creek valley and grades into lacustrine delta deposits of the Milton delta (which formed in a local ice-marginal lake), and many bedrock exposures are found in the northwestern corner of the quadrangle, where elevations exceed $1,000 \mathrm{ft}$.

\section{Round Lake Quadrangle}

Lacustrine sand plains and dune fields cover much of the eastern half of this quadrangle (pl. 5), and till covers the high elevations in the western half. The most prominent features are several postglacial drainage channels that have been incised into the surficial material without subsequent infilling (Dineen and Hanson, 1983). Several present-day drainage courses (Ballston Lake, Ballston Creek, Mourning Kill, Drummond Creek, Round Lake, and Anthony Kill) occupy these postglacial drainage channels.

Downcutting of the streambed, followed in some areas by minor postglacial deposition, has resulted in a pattern of surficial deposits parallel to, and exposed along, the channel walls or in the thalweg of the channel. The surficial geology along these channels reflects the local topography: the Ballston Lake, Ballston Creek, and Mourning Kill are characterized by bedrock exposures along the channel walls, whereas Drummond Creek and Round Lake-Anthony Kill channel sections are characterized by till and lacustrine silt and clay. 


\section{Mechanicville Quadrangle}

The area shown in the southern half of this quadrangle ( $\mathrm{pl.}$ 6) is covered mostly by lacustrine sand, silt, and clay deposits, which are punctuated by occasional till or bedrock hills or kame deposits. Within this half of the quadrangle, the Anthony Kill valley, a postglacial stream channel, contains till or bedrock outcrops along the valley walls and thin fluvial gravel deposits along its southern edge. The only substantial kame deposits in the quadrangle are north of the Anthony Kill at Willow Glen and in the area east of the Mechanicville Reservoir.

A large alluvial terrace occupies the western side of the Hudson River valley from Stillwater Junction to Bemis Heights. This terrace borders a nearly $3 / 4$-mi-wide alluvial flood plain just north of Stillwater. The northern part of the quadrangle, west from the Hudson River alluvial deposits, is covered mostly by lacustrine deposits of glacial Lake Albany. The area southwest of Schuyler Creek is overlain mostly by lacustrine silt and clay, and the area northeast of Schuyler Creek contains about equal areas of (1) lacustrine silt and clay and (2) till and bedrock. The northwestern part of this quadrangle contains areas of lacustrine sand that have been reworked to form extensive dune fields.

\section{Niskayuna Quadrangle}

The part of the Niskayuna quadrangle (pl. 7) that lies within Saratoga County is dominated by lacustrine sediments associated with glacial Lake Albany: The western half of the mapped area contains till and lacustrine silt and clay and is bordered on the east by a north-south-trending band of lacustrine beach and deltaic deposits. The eastern half of the quadrangle contains extensive lacustrine-sand plains and dune fields. These deposits are underlain in places by older ice-contact sand and gravel deposits that are locally exposed at land surface. The southern limit of the study area (the Mohawk River) is bordered by alluvial-terrace deposits, till, lacustrine silt and clay, and bedrock

\section{Troy North Quadrangle}

Most of the mapped area in this quadrangle (pl. 8) was inundated by glacial Lake Albany, as evidenced by the lacustrine sand, silt, and clay that cover nearly all of the mapped area. Exceptions include sporadic till hills, occasional bedrock outcrops along the Mohawk River, and continuous alluvium along the Hudson River. Alluvium along the west bank of the Hudson River forms a flood plain as much as ${ }^{3 / 4}$ mi wide that contains several alluvial fans.

\section{TYPES OF AQUIFERS}

Ground water is pumped from unconsolidated deposits and bedrock within the study area; the unconsolidated aquifers are generally more productive and, thus, are more widely used than bedrock aquifers. The hydraulic characteristics of unconsolidated deposits are summarized in table 2. The most productive aquifers are in unconsolidated deposits of outwash, kame, lacustrine delta, and, to a lesser extent, lacustrine sand of Pleistocene age.

\section{Kame Deposits}

Kame deposits in preglacial bedrock channels, such as the Colonie channel (Simpson, 1949), are overlain by lacustrine silt and clay and form discontinuous, but productive, confined aquifers ranging up to $100 \mathrm{ft}$ thick (Dineen and Hanson, 1983; Waller, 1983; Reynolds, 1985; Dunn Geoscience, 1981). One such confined aquifer system, the Colonie channel aquifer, supplies water to several developments in the Town of Clifton Park (Dunn Geoscience, 1981; Reynolds, 1985). Well yields as high as 800 $\mathrm{gal} / \mathrm{min}$ have been reported (Dunn Geoscience, 1981), although most supply wells yield far less as a result of well design, small aquifer extent, pumping limitations imposed by the design of the distribution system, or interference from nearby production wells. Outcrops of kame deposits adjacent to the buried channel probably serve as recharge areas for the confined aquifer (Reynolds, 1985). Confined aquifers are susceptible to contamination by human activities within these recharge areas.

The locations and extent of confined kame deposits are not discernible on plates 1 through 8 , but the buried-channel locations provide a starting point for future subsurface investigations. Neither the composition of buried valley 
deposits north of Saratoga Lake nor the waterresources potential of most surficial kame deposits is known.

\section{Lacustrine Deltaic Deposits}

Lacustrine deltaic deposits form productive aquifers in at least two locations in the study area-(1) the Milton delta (labeled ld) west of Saratoga Springs (pl. 3) and (2) a confined deltaic deposit northwest of West Milton (pl. 4). The Milton delta supplies several housing tracts and parts of the City of Saratoga Springs and the Village of Ballston Spa. The largest withdrawals are from the Geyser Crest well field (Saratoga Springs quadrangle, pl. 3), where six wells are screened within $60 \mathrm{ft}$ of land surface and where the maximum individual well yield is reported to be between 600 and $700 \mathrm{gal} / \mathrm{min}$ (Dunn Geoscience, 1988). A confined aquifer composed of lacustrine deltaic sand is the principal source of water for the Kenneth A. Kesselring site (fig. 2), a Federal Government reactor-research installation, at West Milton. Studies of this aquifer suggest that yields of $800 \mathrm{gal} / \mathrm{min}$ can be obtained from a single well (Mack, 1963).

\section{Lacustrine Sand, Outwash Sand and Gravel, and Alluvium}

These deposits typically form thin, unconfined aquifers, and their proximity to land surface makes them more susceptible than confined aquifers to contamination from human activities, such as septic waste and road salt. Lacustrine sand deposits form the most widespread aquifers in the study area. Hydraulic properties of the aquifer at the Saratoga $\mathrm{Na}$ tional Historical Park (pls. 2, 6; fig. 2) were investigated by Heath and Tannenbaum (1963),

Table 2.-Hydraulic characteristics of unconsolidated deposits in the study area.

\begin{tabular}{|c|c|}
\hline $\begin{array}{l}\text { Map } \\
\text { Symbol }\end{array}$ & Description \\
\hline al & $\begin{array}{l}\text { FLOOD-PLAIN ALLUVIUM-Associated with large streams and rivers. Has potential for } \\
\text { water supply by induced infiltration of surface water into the aquifer by pumping. Permeabil- } \\
\text { ity varies with local sediment character of basin. Alluvium is generally not considered a major } \\
\text { source of ground water within small stream valleys, where its thickness and extent is typically } \\
\text { limited. }\end{array}$ \\
\hline alt & ALLUVIAL TERRACE-Generally permeable; commonly unsaturated. \\
\hline alf & ALLUVIAL FAN-Generally permeable but of limited extent; commonly unsaturated. \\
\hline de & RECENT DELTA-Generally permeable but of limited extent. \\
\hline d & DUNES-Permeable; commonly unsaturated. \\
\hline $\mathrm{pm}$ & SWAMP DEPOSITS-Generally impermeable. \\
\hline lb & $\begin{array}{l}\text { BEACH SAND AND GRAVEL-Permeable but limited in areal extent and thickness; generally } \\
\text { unsaturated. }\end{array}$ \\
\hline ld & LACUSTRINE DELTA-Generally permeable and productive where saturated. \\
\hline ls & LACUSTRINE SAND-Permeable; saturated thickness could limit invidiual well yield. \\
\hline lsc & $\begin{array}{l}\text { LACUSTRINE SILT AND CLAY-Typically impermeable; generally a confining unit where } \\
\text { underlain by permeable deposits. }\end{array}$ \\
\hline fg & FLUVIAL GRAVEL-Generally permeable; commonly unsaturated. \\
\hline og & $\begin{array}{l}\text { OUTWASH SAND AND GRAVEL-Permeable, with potential for induced infiltration of surface } \\
\text { water where in hydraulic connection with streams or rivers. }\end{array}$ \\
\hline $\mathbf{k}$ & KAME DEPOSITS-Permeable and productive where saturated. \\
\hline cd & COMPLEX DRIFT-highly variable permeability. \\
\hline $\mathbf{t}$ & $\begin{array}{l}\text { TILL-Low permeability; can yield small amounts of water to large-diameter ( } 2 \mathrm{ft} \text { or greater) } \\
\text { dug wells; water is derived primarily from local sand lenses within the till. }\end{array}$ \\
\hline $\mathbf{t} \mathbf{t}$ & THIN TILL-Low permeability, commonly unsaturated, yields little water. \\
\hline tw & $\begin{array}{l}\text { WASHED TILL-Small areal extent and thickness; can be permeable, depending on the degree } \\
\text { of sorting. }\end{array}$ \\
\hline
\end{tabular}


who used aquifer-test data to estimate a horizontal hydraulic conductivity of $94 \mathrm{ft} / \mathrm{d}$ and a storage coefficient of 0.16 . The saturated thickness of these relatively thin aquifers could limit the long-term yield of wells. Several municipal and private subdivision suppliers tap these aquifers; the maximum reported withdrawal from these unconsolidated aquifers within the study area (table 3, pumping site 13 ; pl. 3 ) is $250,000 \mathrm{gal} / \mathrm{d}$. Saturated outwash sand and gravel and alluvium in the valley of Kayaderosseras Creek (pl. 4) also represent a potential water source. Although these deposits are less extensive than those previously mentioned, downward gradients caused by pumping can induce flow from the creek and tributary streams into the shallow aquifer and thereby increase the amount of water available for pumping. Water pumped from a shallow collector well near Kayaderosseras Creek at West Milton (pl. 4) supplied the Kenneth A. Kesselring site (fig. 2) for 8 years and was capable of yielding $750 \mathrm{gal} / \mathrm{min}$ for extended periods (Mack, 1963), although the maximum yield fluctuated seasonally with the level of Kayaderosseras Creek.

\section{Bedrock}

The most productive bedrock aquifers in the study area consist of carbonates and sandstone that form the bedrock surface along the northwestern edge of the study area. Much of the remaining study area is underlain by shale with the most productive zone, in terms of yield and water quality, being a fractured and weathered layer near the bedrock surface. Well yield tends to decrease, and water mineralization tends to increase, with depth. Fractured crystalline rock is used as a source of water in some areas near the northwestern boundary of the study area. Most bedrock aquifers within the study area are confined by till or fine-grained lacustrine sediments. Heath (1963) lists average yields for wells completed in bedrock in Saratoga County as follows: shale, $10 \mathrm{gal} / \mathrm{min}$; carbonate rock, 30 $\mathrm{gal} / \mathrm{min}$; sandstone, $20 \mathrm{gal} / \mathrm{min}$; and crystalline rock, $5 \mathrm{gal} / \mathrm{min}$. Well yields from the bedrock, which depend on secondary permeability (fractures), vary widely and are difficult to predict before test drilling and pumping.

\section{GROUND-WATER PUMPAGE IN 1988-89}

Pumpage data from suppliers that average at least $10,000 \mathrm{gal} / \mathrm{d}$ were compiled from the New York State Department of Health data base and from telephone interviews with suppliers (table 3 ). The resulting data set includes water supplies for municipalities and private subdivisions, apartment complexes and condominiums, mobile-home parks, private industry, and government facilities; seasonal and commercial pumpage was not compiled. Table 3 lists the supplier; the $7^{\frac{1}{1}} / 2$-minute quadrangle in which it is located; the average daily pumpage; general aquifer type; and the number, type, and depth of the production wells (where available). The location of each supplier is shown on plates 1 through 8.

Ground-water pumpage for domestic use far exceeds that for industrial use within the study area (table 4). Because many industrial plants require large amounts of water for certain processes, such as cooling, they are commonly built near surface-water bodies (Hudson and Mohawk Rivers, Kayaderosseras Creek), where large quantities of water are readily available.

Of the $\mathbf{4 8}$ ground-water suppliers listed in table 3,69 percent tap unconsolidated aquifers, 21 percent tap bedrock aquifers, and 10 percent tap both types of aquifer. Unconsolidated aquifers are the more productive source, however, and are the source for all withdrawals of more than $100,000 \mathrm{gal} / \mathrm{d}$ in the study area.

Water in unconsolidated aquifers can be divided into two general depth categoriesshallow (less than $50 \mathrm{ft}$ ) and deep (greater than or equal to $50 \mathrm{ft}$ ). Most withdrawals of shallow ground water are from extensive lacustrine sand deposits, but alluvium, fluvial gravels, and outwash gravels are important shallow sources locally. Other permeable surficial deposits (listed in table 2) can also serve as aquifers, provided that they have sufficient saturated thickness to support the intended pumpage. Most withdrawals of shallow ground water are from unconfined aquifers, and most withdrawals of deep ground water are from confined aquifers in buried valleys or thick deltaic deposits. 
Table 3.-Average daily pumpage (1988-89), aquifer type, and well data from suppliers that withdraw at least 10,000 gallons per day, in eastern Saratoga County, arranged by facility,.

[Data from New York State Department of Health and telephone interviews; gal/d = gallons per day.

NA Data not available. * Estimated from available data. ** Design capacity upon completion.] Designation
of pumping
site (see pls. 1-8)

$\begin{array}{llc} & \begin{array}{c}\text { Average } \\ \text { daily } \\ \text { pumpage } \\ \text { Sul/d) }\end{array} \\ \text { Suad- } & \begin{array}{l}\text { (gangle } \\ \text { ra }^{\mathrm{a}}\end{array} & \end{array}$

General

type of Number and types of wells ${ }^{c}$, and well Aquifer $b$ depths, in feet below land surface

\section{MUNICIPALITY OR PRIVATE SUBDIVISION}

\begin{tabular}{|c|c|c|c|c|c|c|}
\hline 1 & Village of Ballston Spa & SAR & 576,000 & $\mathbf{U}$ & 1 & well - 80 \\
\hline 2 & Calico Colony-Woodland Hills & NIS & 80,000 & $\mathbf{U}$ & 3 & wells $-62,62,66$ \\
\hline 3 & Clifton Gardens Water Supply & NIS & 150,000 & $\mathbf{U}$ & $\begin{array}{l}15 \\
13\end{array}$ & $\begin{array}{l}\text { driven wells - } 20 \\
\text { driven wells - } 20\end{array}$ \\
\hline & & & & & 3 & wells - $156,164,153$ \\
\hline 4 & Colonial Green Water Supply & NIS & 50,000 & $\mathrm{U}$ & 3 & wells $-53,83,80$ \\
\hline 5 & Colonial Hills Water Co. & SAR & $98,000 * *$ & B & 2 & wells $-205,205$ \\
\hline 6 & Country Knolls Water Works, Inc. & & $1,491,000$ & $\mathrm{U}$ & 9 & sites: \\
\hline A & Elnora well field & RDL & & & $12 \mathrm{dr}$ & iven wells-26 to 32 \\
\hline B & Kinns Road well field & & & & $1 \mathrm{w}$ & vell-112 \\
\hline $\mathrm{C}$ & Pierce Farm well field & RDL & & & & vell-130 \\
\hline D & Moe Road well field & RDL & & & & vell-165 \\
\hline $\mathbf{E}$ & Lapp Road, well field & NIS & & & & vells-132, 132 \\
\hline $\mathbf{F}$ & Plank Road, well field & NIS & & & $1 \mathrm{w}$ & vell-185 \\
\hline G & Golf course, well field & RDL & & & $2 \mathrm{w}$ & vells-90, 90 \\
\hline $\mathrm{H}$ & Northcrest well field & NIS & & & infilt & ration well-20 to 25 \\
\hline $\mathrm{I}$ & Sherwood Forest well field & $\begin{array}{l}\text { NIS } \\
\text { RDL }\end{array}$ & & & & wells $-25,25,25$ \\
\hline 7 & Crescent Estates & NIS & 325,000 & $\mathbf{U}$ & 4 & wells - 148, 150, 134, 134 \\
\hline 8 & Geyser Crest-Heritage Knolls & SAR & $1,013,000$ & $\mathrm{U}$ & 6 & wells - all between 52 to 57 \\
\hline 9 & Gilbert Road Water Works & QSP & 10,000 & $\mathrm{U}$ & 2 & wells - both between 110 to 120 \\
\hline 10 & Heritage Springs Water Co. & SAR & 30,000 & B & 3 & wells $-170,170,210$ \\
\hline 11 & Interlaken Water Works & QSP & 40,000 & $\mathrm{U}$ & 3 & wells - 155 each \\
\hline 12 & Laurel Acres & SAR & 12,000 & $\mathbf{U}$ & 2 & wells - 38 each \\
\hline 13 & Luther Forest & RDL & 250,000 & $\mathrm{U}$ & 5 & wells - all between 32 to 35 \\
\hline 14 & Park Lane Estates Water Works & NIS & 30,000 & $\mathrm{U}$ & 4 & wells - 50 each \\
\hline 15 & Rowlands Hollow Water Co. & SAR & 45,000 & $\mathrm{U}, \mathrm{B}$ & 3 & $\begin{array}{l}\text { wells }-112 \text { and } 100 \text { to } 120 \text { in unconsol. } \\
\text { idated material, } 183 \text { in bedrock }\end{array}$ \\
\hline 16 & Pine North & SAR & 12,000 & $\mathrm{U}$ & 1 & spring-fed cistern \\
\hline 17 & Village of Stillwater & MEC & 320,000 & $\mathrm{U}$ & 5 & wells - all between 24 to 39 \\
\hline 18 & Terel Hills & GAN & 30,000 & $\mathrm{U}$ & 3 & wells $-87,92,90$ \\
\hline
\end{tabular}

\section{APARTMENT COMPLEX}

\begin{tabular}{|c|c|c|c|c|c|c|}
\hline 19 & Brookline Village & RDL & 25,000 & B & 8 & wells -75 to 150 \\
\hline 20 & Clifton Park & NIS & 24,000 & $\mathrm{U}$ & 3 & wells - 70 each \\
\hline 21 & English Village & GAN & 16,150 & $\mathrm{U}$ & 2 & wells - 180 each \\
\hline 22 & London Square & NIS & 12,000 & $\mathbf{U}$ & 2 & wells - 120, 90 \\
\hline 23 & McGregor Mini-mart & GAN & 10,000 & $\mathbf{U}$ & 4 & driven wells - 25 to 35 \\
\hline 24 & Parkwood Village & TYN & 14,000 & B * & 3 & wells - 150 each \\
\hline 25 & Squire Park & NIS & 10,000 & & 3 & wells - NA \\
\hline 26 & Twin Lakes & NIS & 75,000 & $\mathbf{U}$ & 1 & well - 81 \\
\hline
\end{tabular}

a Quadrangle abbreviations: GAN (Gansevoort) QSP (Quaker Springs) SAR (Saratoga Springs) MGR (Middle Grove)
RDL (Round Lake) MEC (Mechanicville) NIS (Niskayuna) TYN (Troy North) c Well types include: wells - drilled unless specified otherwise driven wells - well points, typically less than $35 \mathrm{ft}$ deep dug wells - typically less than $25 \mathrm{ft}$ deep infiltration gallery -large-diameter casings, typically less than $25 \mathrm{ft}$ deep

b U unconsolidated; B bedrock 
Table 3.-Average daily pumpage (1988-89), aquifer type, and well data from suppliers that withdraw at least 10,000 gallons per day, arranged by facility, in eastern Saratoga County (continued).

\begin{tabular}{|c|c|c|c|c|c|c|}
\hline $\begin{array}{c}\text { Designation } \\
\text { of pumping } \\
\text { site (see pls. } \\
1-8 \text { ) } \\
\end{array}$ & Supplier & \multirow[t]{2}{*}{$\begin{array}{l}\text { Quad- } \\
\text { rangle a }\end{array}$} & \multirow[t]{2}{*}{$\begin{array}{l}\text { Average } \\
\text { daily } \\
\text { pumpage } \\
\text { (gal/d) }\end{array}$} & \multirow[t]{2}{*}{$\begin{array}{l}\text { General } \\
\text { type of } \\
\text { Aquifer } b\end{array}$} & \multicolumn{2}{|c|}{$\begin{array}{l}\text { Number and types of wells } \mathbf{c} \text {, and well } \\
\text { depths, in feet below land surface }\end{array}$} \\
\hline \multicolumn{4}{|c|}{ MOBILE HOME PARK } & & & \\
\hline 27 & Adirondack Estates & GAN & 11,000 & $\mathrm{U}$ & $10 w$ & ells - NA \\
\hline 28 & Brookview & SAR & 35,000 & B & 1 & well - 100 \\
\hline 29 & Cobblestone & QSP & 22,000 & $\bar{U}$ & 3 & driven wells - NA \\
\hline 30 & Creek and Pines & MGR & 35,000 & $\mathrm{U}$ & 2 & driven wells - NA \\
\hline 31 & $\mathrm{D}$ and $\mathrm{R}$ & NIS & 35,000 & $\mathrm{U}, \mathrm{B}$ & 4 & $\begin{array}{l}\text { wells - } 2 \text { in bedrock - } 70,235 \\
2 \text { in unconsolidated material - } \\
40 \text { each }\end{array}$ \\
\hline 32 & Ebert's Trailer Town & SAR & 14,000 & U, B & $\begin{array}{l}8 \\
3\end{array}$ & $\begin{array}{l}\text { driven wells } 15 \text { to } 25 \\
\text { wells - } 97 \text { (probably in bedrock) } \\
74,79 \text { (probably in unconsolidated } \\
\text { deposits) }\end{array}$ \\
\hline 33 & Hidden Acres & SAR & 14,000 & B & 1 & well - 100 \\
\hline 34 & Loughberry & SAR & $14,300 *$ & $\mathrm{U}$ & 4 & driven wells -35 to 45 \\
\hline 35 & Malta Gardens & RDL & 40,000 & $\mathrm{U}$ & 4 & wells - 30 each \\
\hline 36 & Malta Mobile Acres & RDL & 16,000 & $\mathbf{U}$ & 2 & dug wells - NA ${ }^{\mathrm{d}}$ \\
\hline 37 & Martindale Court & NIS & 15,000 & $\mathbf{U}$ & 1 & well - 35 \\
\hline 38 & Northern Pines & MGR & 40,000 & $\mathrm{U}$ & 3 & infiltration wells - $15,15,25$ \\
\hline 39 & Northway Mobile Estates & $\mathrm{RDL}$ & 11,000 & $\mathrm{U}$ & 6 & wells - 100 to 150 \\
\hline 40 & Pyramid Pines & QSP & 30,000 & $\mathbf{U}$ & 13 & driven wells - NA \\
\hline 41 & Stockade & MGR & 20,000 & $\mathrm{~B} *$ & 4 & wells - $180,180,280,280$ \\
\hline 42 & Terrace Hill Commons & MGR & 22,000 & B & 7 & wells -5 between 240 to 385,2 are 700 \\
\hline 43 & Turf & NIS & 119,000 & $\mathrm{U}, \mathrm{B}$ & 6 & $\begin{array}{l}\text { wells }-78,85 \text {, four wells between } 100 \\
\text { and } 170 ; 2 \text { deepest wells in bedrock }\end{array}$ \\
\hline 44 & Utter's Mobile Estates & SAR & 11,000 & B & 2 & wells - 119,121 \\
\hline 45 & Vosburg Road & RDL & 15,200 & $\mathrm{U}, \mathrm{B}$ & 2 & $\begin{array}{l}\text { wells - } 115,160 \text { in bedrock } \\
1 \text { infiltration gallery - } 10\end{array}$ \\
\hline 46 & Wilton Mobile Park & QSP & 30,000 & $\mathrm{U}$ & 6 & driven wells - between 19-21 \\
\hline
\end{tabular}

PRIVATE INDUSTRY

\begin{tabular}{cllllll}
\hline 47 & General Foods & SAR & $200,000 *$ & U & 1 well - 83 \\
\hline GOVERNMENT INSTALLATION & & & & \\
\hline 48 & $\begin{array}{l}\text { Kenneth A. Kesselring } \\
\text { Site }\end{array}$ & MGR & $2,600,000$ & U & 7 wells - 105, 99, 100, 72, 25, 25, 122 \\
\hline
\end{tabular}


Table 4.-Pumpage totals, by supplier (See table 3.)

\begin{tabular}{lc}
\hline \multicolumn{1}{c}{ Type of Supplier } & $\begin{array}{c}\text { Pumpage, in } \\
\text { gallons per day }\end{array}$ \\
\hline Municipalities and subdivisions & $4,562,000$ \\
Apartment complexes and & 186,150 \\
condominiums & \\
Mobile home parks & 549,500 \\
Private industry & 200,000 \\
Government installations & $2,600,000$ \\
\hline
\end{tabular}

Every category of supplier listed in table 3 has wells generally less than $50 \mathrm{ft}$ deep that are screened in shallow aquifers, but small suppliers withdraw a larger percentage of their water from shallow aquifers than the large suppliers do. For example, 65 percent of mobile-home parks have wells screened in shallow aquifers, whereas only 33 percent of municipalities and private subdivisions have these wells. The difference in usage reflects differences in:
1. Water needs. - Thin, near-surface aquifers meet the needs of small suppliers more readily than those of large suppliers.

2. Economics. -Shallow wells, particularly driven wells, are less expensive to install than deep, typically large-diameter wells.

3. Location.-Several municipalities and private subdivisions are directly above or near the Colonie buried bedrock channel, whereas most mobile-home parks are scattered about the study area, away from known confined aquifers in these channels.

Most of the deep wells that are screened in unconsolidated aquifers belong to municipal and private subdivision suppliers. The most common sources of water at these depths are saturated kame and lacustrine deltaic deposits, and most production wells screened in these deposits are between 100 and $200 \mathrm{ft}$ deep.

\section{SUMMARY}

Aquifers are the sole source of water for most domestic development in eastern Saratoga County; therefore, information on the stratigraphy, surficial geology, types of aquifers, and groundwater pumpage can be helpful for development and protection of this resource. The USGS, in cooperation with the Saratoga County Environmental Management Council, began a study in 1988 to compile and analyze data on the groundwater resources of the eastern part of the county.

The study area is underlain by a dissected bedrock surface that has been further modified by erosional processes associated with glaciation. Pleistocene and Holocene (recent) deposits blanket much of the bedrock surface and fill the preglacial drainage channels. The glacial deposits can be divided into the general categories of till, ice-contact, lacustrine, and outwash deposits. Lacustrine deposits are the predominant surficial material at elevations below the maximum glacial-lake stage, which increases in elevation to the north; till and ice-contact deposits predominate above that level but also are found beneath the lacustrine deposits.
The study area contains aquifers that consist either of unconsolidated sediments or bedrock. The unconsolidated sediments, such as kame and lacustrine delta deposits, form the most productive aquifers, which can be confined or unconfined. Lacustrine sand and outwash deposits form productive unconfined aquifers near land surface, but they are more susceptible to contamination from surface sources than confined aquifers. In general, bedrock aquifers are less productive than the unconsolidated aquifers, are typically confined, and contain more highly mineralized water.

Most of the pumped ground water is from unconsolidated, Pleistocene-age aquifers. The primary use is for domestic purposes; private industry uses mostly surface-water sources. Lacustrine delta and buried-channel kame deposits are tapped by the largest ground-water users; aquifers composed of lacustrine sand and, to a lesser extent, aquifers composed of outwash, are pumped in parts of the study area where the more productive aquifers are absent or where water demands are low. 


\section{REFERENCES CITED}

Cadwell, D.H., and Dineen, R.J., 1980-1988, Surficial geologic maps of the Gansevoort, Mechanicville, Middle Grove, Niskayuna, Round Lake, Quaker Springs, Saratoga Springs, and Troy North $7{ }^{1 / 2}$-minute quadrangles: Albany, N.Y., New York State Geological Survey-New York State Museum, Open-File Maps, scale 1:24,000.

DeSimone, D.J., and LaFleur, R.G., 1985, Glacial geology and history of the northern Hudson basin, New York and Vermont, in Lindemann, R.H., ed., 1985, Field trip guidebook: New York State Geological Association, 57th Annual Meeting, Saratoga Springs, N.Y., p. 82-116.

Dineen, R.J., 1975-88, Bedrock-surface maps of the Gansevoort, Mechanicville, Middle Grove, Quaker Springs, Round Lake, and Saratoga Springs $7 \frac{1}{1} 2^{\text {-minute quadrangles: }}$ Albany, N.Y., New York State Geological Survey-New York State Museum, Open-File Maps, scale 1:24,000.

Dineen, R.J., and Hanson, E.L., 1983, Bedrock topography and glacial deposits of the Colonie Channel between Saratoga Lake and Coeymans, New York: New York State Museum Map and Chart Series, no. 37, 55 p.

Dineen, R.J., and Rogers, W.B., 1979, Trip A3Sedimentary environments in Glacial Lake Albany in the Albany section of the HudsonChamplain Lowlands, in Friedman, G.M., ed., Guidebook to field trips: New York State Geological Association, 51st Annual Meeting, Troy, N.Y., p. 87-119.

Dunn Geoscience Corporation, 1981, Hydrogeologic investigations of the Colonie channel aquifers, Town of Clifton Park, New York: Latham, N.Y.; Dunn Geoscience Corp., 10 p., 4 pl. 1982, Hydrogeologic investiation of the aquifer recharge areas, Town of Clifton Park, New York: Latham, N.Y.; Dunn Geoscience Corp., 5 p., 1 pl. 1988, Phase one evaluation of groundwater resources, Kayaderosseras Delta, Saratoga County, New York: Albany, N.Y.; Dunn Geoscience Corp., 25 p., 3 pl.

Fairchild, H.L., 1916, Postglacial features of the upper Hudson valley: New York State Museum Bulletin 195, 22 p., 1 pl.
Hanson, E.L., 1977, Late Woodfordian drainage history in the lower Mohawk Valley, Troy, N.Y.: Rensselaer Polytechnic Institute, unpublished master's thesis, $61 \mathrm{p}$.

Heath, R.C. 1963, Summary of ground-water conditions in Saratoga County, in Heath, R.C., Mack, F.K., and Tannenbaum, J.A., 1963, Ground-water studies in Saratoga County, New York: New York State Water Resources Commission Bulletin GW-49, p. 3-42.

Heath, R.C. and Tannenbaum, J.A., 1963, Ground-water resources of Saratoga National Historic Park, in Heath, R.C., Mack, F.K., and Tannenbaum, J.A., 1963, Groundwater studies in Saratoga County, New York: New York State Water Resources Commission Bulletin GW-49, p. 77-125.

LaFleur, R.G., 1965, Trip C - Glacial lake sequences in the eastern Mohawk - northern Hudson region, in Hewitt, P.C. and Hall L.M., eds., 1965, Guidebook to field trips in the Schenectady area: New York State Geological Association, 37th Annual Meeting, Schenectady, N.Y., p. C1-C23. 1979, Trip B6 - Deglacial events in the eastern Mohawk-northern Hudson Lowland, in Friedman, G.M., ed., 1979, Guidebook to field trips: Joint annual meeting - New York State Geological Association, 51st annual meeting and New England Intercollegiate Geological Conference, 71st annual meeting, Troy, N.Y., p. 326-350.

Mack, F.K., 1963, Geology and ground-water resources of the West Milton Area, in Heath, R.C., Mack, F.K., and Tannenbaum, J.A., 1963, Ground-water studies in Saratoga County, New York: New York State Water Resources Commission Bulletin GW-49, p. 43-76.

Mack, F.K. Pausek, F.H., and Crippen, J.R., 1964, Geology and hydrology of the West Milton area, Saratoga County, New York: U.S. Geological Survey Water-Supply Paper 1747, 110 p., 6 pl.

Reynolds, R.J., 1985, Hydrogeology of the Clifton Park area, Saratoga County, New York: U.S. Geological Survey Water-Resources Investigations Report 84-4031, 7 pl., scale 1:24,000. 


\section{REFERENCES CITED (Continued)}

Simpson, E.S., 1949, Buried preglacial ground water channels in the Albany-Schenectady area in New York: New York State Water and Power Control Commission Bulletin GW-20A, p. 713-720.

Stoller, J.H., 1916, Glacial geology of the Saratoga quadrangle: New York State Museum Bulletin 183, 50 p.
Waller, R.M., 1983, Ground-water potential of the Capital District buried-valley deposits, in Dineen, R.J., and Hanson, E.L., 1983, Bedrock topography and glacial deposits of the Colonie Channel between Saratoga Lake and Coeymans, New York: New York State Museum Map and Chart Series, no. 37, 55 p. 
